\title{
The construction of higher education students within national policy: a cross-European comparison
}

\author{
Rachel Brooks, University of Surrey, UK
}

\begin{abstract}
It is often assumed within much of the academic literature and by many of those working in higher education that universities across Europe are homogenising, converging around an Anglo-American model as a result of neo-liberal pressures and the aim of creating a single European Higher Education Area. However, drawing on an analysis of 92 policy documents from six different European countries, this article demonstrates that enduring differences remain - at least in so far as constructions of students are concerned. While European policy may assume that higher education students can move unproblematically across national borders, as part of the Erasmus mobility scheme, for example, we show that understandings of 'the student' differ in significant ways both across countries and, to some extent, within them. This has implications for both European policy and academic theorisation.
\end{abstract}

Keywords: higher education, students, policy, Europe 


\section{The construction of higher education students within national policy: a cross-European comparison}

\section{Introduction}

This article draws upon an analysis of documents produced by a wide range of policy actors across Europe to explore the ways in which higher education (HE) students are understood. It seeks to generate new knowledge about the nature of such constructions, and the extent to which they vary across the continent. In doing so, it engages with arguments - made within much of the academic literature and by many of those working in higher education - that universities across Europe are homogenising. Scholars have contended that, as a result of globalising pressures, the influence of neo-liberalism, and policies to develop a European Higher Education Area, higher education systems are converging around an Anglo-American model, with students frequently positioned as consumers (e.g. Batory and Lindstrom, 2011; Moutsios, 2013; Voegtle et al., 2011; Wright and Shore, 2017). However, this article demonstrates that enduring differences remain - at least in so far as policy constructions of students are concerned. While various European initiatives ${ }^{i}$ may assume that higher education students can move unproblematically across national borders, as part of the Erasmus mobility scheme, for example, we show that understandings of 'the student' differ in significant ways both across countries and, to some extent, within them. This has implications for both European policy and academic theorisation.

The first part of the article situates the research within extant bodies of knowledge, examining both the significance of policy constructions and previous work on understandings of higher education students, specifically, within policy. It then goes on to outline the 
methods that were used to select and analyse the higher education policies, before presenting some of the key points of difference that emerged from the analysis. The final part of the article considers how these differences can best be explained, drawing links to the wider socio-political context including the mechanisms through which higher education is funded.

\section{Background}

Policy is now widely understood, not as a simple response to societal concerns, but as a means through which social problems and our view of the world more generally are shaped. Indeed, as Bacchi (2000) has argued, governments do not respond to problems 'out there' but commonly construct such problems through the very policy proposals that are offered as solutions. This perspective draws on a materialist view of language in which words are understood as doing more than naming things; they impose limits on what can be said and whose voices are viewed as legitimate. It is also informed by the work of Foucault and others on discourse. Discursive formations are 'practices that systematically form the objects of which they speak' (Foucault, 1986, p.49); they construct certain possibilities for thought by ordering and combining words in particular ways and excluding or displacing other combinations (Ball, 1990, p.18). From this perspective, language is seen as inherently political: any definition of a word inevitably makes claims about how it should be used rather than describing how it is used. Thus, close reading of a policy text, attentive to the language that is deployed, can help to make more visible policy processes and the values and understandings that underpin them.

It is important, however, not to view policy texts in isolation; they often act upon and influence one another intertextually (Maguire et al., 2011). This is illustrated well in Sabri's 
(2010) work on higher education policy formation in the UK. She argues that, together, policy texts generate 'assumptive worlds', which can limit what any one policy actor or policy text can say. She writes: 'This assumptive world transcends the boundaries of discrete organisations in terms of the policy spaces they occupy and it is sustained beyond the often transitory or precarious existence of these organisations. The scope for individual agency among policymakers is therefore circumscribed by the convergence among higher education agencies on particular issues of policy development' (p. 202). Nevertheless, dominant discursive formations are not totalising phenomena - they are often fragile, and commonly contain gaps, absences and sometimes contradictions (Maguire et al., 2011; O’Connor, 2018). Moreover, discourses can be translated and modified as they move across time and space. For example, Zippel et al. (2016) demonstrate how gender equality advocates within the German higher education system systematically exploited neo-liberal discourses around 'inclusive excellence' to advance a wide range of programmes to promote the position of women. Advocates contended that competition was a sign of excellence and women were a key resource for Germany in its competition with other knowledge economies. Similarly, Capano and Piattoni (2011) - writing with reference to England, Germany, the Netherlands and Italy - have argued that European higher education policy acts primarily as a 'script' that national policy actors follow and interpret according to their own cultural, political and institutional traditions.

Such perspectives have informed various previous studies of the ways in which students have been constructed in policy. Sabri has argued that UK policy tends to understand students as consumers and/or technical learners. They are, she contends, 'central to higher education policymaking and their interests are best served [policy suggests] by improving "the student experience" and providing them, as paying customers, with information to make 
choices' (p.201). Some similarities are noted by Tavares and Cardoso (2013), who contend that the consumer metaphor has had some influence, and is increasingly dominant within policy, in Portugal. Research conducted by Nielsen and Sarauw (2017) has shown how recent higher education policy in Denmark has constructed the 'ideal' higher education student as both attuned to the demands of the labour market and attentive to the pace at which they progress through their studies. Students are thus incentivised to 'adopt a certain kind of anticipatory behaviour, redirecting their attention from the learning activities "here and now" towards processes of piecing together and forecasting a particular future in the labour market' (p.156). Focussing more on approaches to learning, Leathwood (2006) maintains that dominant constructions of students within UK higher education policy tend to foreground ideas around independence. This is problematic, she suggests, as it reinforces 'masculinist myths' - 'what suits (some) men is defined as the ideal that all should be striving for, whilst men's dependence on others remains hidden' (p.630). This construction has practical consequences: because dependence is denigrated, students are reluctant to ask for help or attend special classes, as these signify lack or deficiency.

Policies are not always internally consistent and can contain contradictions and tensions. Research has shown, for example, how consumer discourses can be infused with ideas about student vulnerability (Brooks, 2018a), and how understandings of higher education students as employable subjects have mutated across time and space (Sin and Neave, 2016). It is also important to recognise that, although dominant constructions tend to be constructed through processes of intertextuality and the formation of particular 'assumptive worlds', as discussed above, consensus is not always evident; nations should not therefore be considered as coherent educational entities (Philips and Schweisfurth, 2014). In the remainder of this article, we are sensitive to the possibility of multiple constructions of 
the higher education student within a single national context. Indeed, this has informed the research design, as will be explained below. However, in drawing out comparisons between European nations, we place primary emphasis on governmental perspectives, acknowledging that government constructions of the student are likely to have particular influence on the ways in which understandings are shaped across the higher education sector as a whole, and that other policy actors often use the language of government to legitimise their own claims (Ashwin et al., 2015).

\section{Methods}

The article draws on an analysis of 92 policy texts that were collected from six different European countries (Denmark, England, Germany, Ireland, Poland and Spain). The countries were chosen to provide diversity with respect to their: 'welfare regime' (Esping Anderson, 1990); relationship to the European Union (EU); and means of funding higher education. In particular, we were keen to include: countries in which higher education, for full-time undergraduates at least, was fully-funded by the state (Denmark and Poland); nations where students paid low to moderate fees or 'administration costs' (Germany, Ireland and Spain); and England, where fees were very high. Further details about the country characteristics are provided in Table 1.

The data were collected as part of a larger European Research Council-funded project on the ways in which higher education students are understood across Europe, which pays particular attention to similarities and differences both within and between countries. The wider project examines the ways in which students are understood by: policy actors (through an analysis of policy documents and interviews with 'policy influencers'); the media (via an 
analysis of newspaper articles); higher education institutions (through interviews with staff and analysis of institutional websites); and students themselves (by means of focus groups). This article draws on one particular part of the dataset - the policy documents - and seeks to answer the following research questions: (i) How are undergraduate higher education students understood in higher education policy texts (produced by key governmental and nongovernmental policy actors)? (ii) To what extent is there variation in such understandings across Europe, and how can any such variation be explained?

In each of the six countries, approximately 16 policy texts were selected for analysis. This number was chosen to ensure that the analysis across the larger project was manageable but also that some different perspectives could be captured, in line with the points made above about nations not necessarily being coherent educational entities. The sample of 16 comprised speeches given by government ministers for higher education, and key strategy documents, relating to higher education, produced by (i) government, (ii) staff and student unions, and (iii) organisations representing graduate employers (in most cases, four documents were selected from each of the four groups ${ }^{\mathrm{ii}}$ ). Documents were chosen on the basis of their: national significance; relevance to the project's focus (on higher education students); and date of publication (the most recent ${ }^{\mathrm{iii}}$ documents were chosen from those deemed to be most significant and relevant). Those not available in English were translated prior to analysis. In several cases, we also sought advice from the project's advisory board (which included representatives from all the six countries) on the choice of documents. It is important to note, however, that the selection of documents is - because of restrictions of both time and money - necessarily limited, and the sample does not always cover all the key higher education actors for each of the nations in the study. Rectors' conferences, for example, were not included in this sample of documents - although they are represented in 
the interviews with 'policy influencers' (which, as noted above, comprise a separate but complementary part of the wider project).

A relatively large number of the documents were either published in English or an official translation in English was publically-available. (This was the case for 25 of the 60 documents from non-English-speaking countries.) Those not available in English in this way were translated prior to analysis. The translations were completed by professional translators who provided notes to the research team about any differences in meaning between the original language and the English translation. Where necessary, advice was also taken from the project's advisory board about the specific meaning of words.

As noted above, the meanings attached to particular terms can change over time; moreover, meanings can vary between stakeholders at any one particular point in time. For this reason, a qualitative, inductive analysis was conducted on the documents, which examined the ways in which particular terms were used, not only their presence or absence. The analysis was, in general, informed by an interpretivist theoretical position, and we sought to understand the meanings of the student from the perspective of the different policy actors. Our focus was on what was said explicitly about students, but also what was implied about them in more general discussions. Moreover, we concentrated primarily on national rather than international students. In the first stage of analysis, the documents were coded in NVivo - using codes derived, inductively, from the documents themselves and informed by the extant literature (Brooks, 2018b). In the second stage of analysis, the coded material was then used to identify dominant themes across the dataset and make comparisons across the different types of policy document (from government, unions and employers' organisations) and the six countries. Explanations for these patterns and themes were subsequently 
developed, making connections to the extant literature. In the following sections of the article, we firstly describe some of the key constructions, noting important variation between countries, before going on to offer some explanations for the identified patterns.

\section{Variation in constructions}

Across all six nations there were some commonalities in how students were constructed in many of the policy documents. For example, a 'future worker' discourse was strong in a large majority of the government documents, foregrounding understandings of students as a 'worker-in-the-making' and the importance of higher education as preparation for labour market engagement (see Brooks, 2018a for a discussion of the English data on this topic). However, in this section we discuss some of the key points of difference across the dataset, to illustrate the enduring variation in understandings within Europe, before going on to offer some explanations for these differences in the subsequent part of the article.

\section{Object of criticism}

There are considerable differences across the documents with respect to the positioning of higher education students as objects of criticism. It is notable that while in the English documents, critical comments are generally directed at the providers of higher education (institutions and those who teach in them) by the government and employers' organisations, and at the government by staff and students' unions, students themselves are constructed in largely very positive terms. Indeed, their hard working nature is emphasised. In contrast, in the other countries, students are problematised, at least to some extent. In Poland and Denmark, such criticisms are bound up with discussions about the massification of higher 
education and the opening up of tertiary education to a significantly greater number of young people. In both nations, students are seen as too numerous and not of sufficient quality. The comments below are illustrative.

In recent years, I find that we have focused too much on quantity, which means the number of students getting through our education system. We wanted as many people as possible to get a higher education degree. It was an understandable and sympathetic ambition. No doubt about that. But time has come to turn our focus to quality. (Danish Speech $1^{\text {iv }}$ )

During the last twenty years, it [HE] was subject to dramatic quantitative and institutional transformations. The establishment of non-public higher education institutions became possible and non-public forms of education were introduced, causing a nearly fivefold increase in the number of students. This huge success in quantitative terms .... has not been accompanied so far by a policy oriented towards a significant improvement in quality. (Polish government document 1)

The expansion of student numbers is discussed much more positively on the whole in Ireland. Nevertheless, one document from the employers' organisation does make a similar comment about the alleged consequences of prioritising quantity over quality in higher education admissions.

Students are also criticised in some of the Polish and Danish documents for making the wrong subject choices - specifically, deciding to focus on humanities rather than those that are perceived to be better aligned to the labour market. 
The structure of the student body, broken down by the main groups of subjects studied, underwent adverse change: we have too many graduates and students in subjects classified as 'social sciences, commerce and law' and 'education', while there may soon be a shortage of graduates in the 'health and social care', 'science', and 'technology, industry and construction' groups. (Polish government document 4)

Finally, the temporal dimension of study is discussed in a number of documents, across different national contexts. In both Germany and Spain, students are commended by the government for having improved the pace of their learning, implying that their past behaviour had been considered problematic. In Denmark they are criticised for still being too slow and taking too much time over their studies: 'Danish students take longer to complete their education than what is intended ... As such, there is still lots of room for improvement' (Danish government document 2).

It should be noted, however, that these perspectives are not shared by all policy actors within the relevant nation states. Indeed, the Danish unions strongly critique the construction of students as slow. Legitimising their arguments by drawing on the government's own framing of higher education as preparation for employment, they contend that employers do not want 'fast learners' but rather those who are more thoroughly prepared for work.

\section{Vulnerable individual}

While students are positioned as objects of criticism by the government in Poland and Denmark, they are understood, in contrast, as vulnerable, or at least potentially vulnerable, in the other four nations. The source of this vulnerability differs considerably, however, across national contexts and between policy actors, and relates closely to the position the particular 
policy actor wishes to advance. In Germany, for example, students are understood by the government, not as 'digital natives' (as they sometimes are in other national contexts - see for example Oliver, 2016), but as vulnerable as a result of the growth of new technologies unless they are better prepared by universities. This underpins its digitisation strategy for the higher education sector. German unions, too, discuss students' vulnerability in relation to new technologies, but from a position that critiques the government's investment in this area. They note, for example, that 'The downside of the high importance of new technologies are increasing risks, such as cybercrime and bullying, content that is harmful to youth, monitoring and, last but not least, the endangerment of jobs' (German union document 5) and argue for appropriate media education to run alongside investment in new technologies. The union also maintains that students may become vulnerable in relation to their learning if universities replace face-to-face contact with online or virtual tuition, while lower income groups may be disadvantaged if students are required to bring their own devices to class (ibid.). A similar use of the image of the vulnerable student - by two different sides in a policy debate - is evident in England. On the one hand, the government argues that students are vulnerable in the face of 'producer interests' (e.g. staff spending more time on their own research and less on engaging with students) and argues that further marketisation (and the establishment of an 'Office for Students') will correct this trend. It contends:

For too long we have been overly tolerant of the fact that some providers have significantly and materially higher drop-out rates than others with very similar intakes in terms of demographics and prior attainment .... it represents thousands of life opportunities wasted, of young dreams unfulfilled ... (English government document 2, p.46) 
On the other hand, the staff union contends that students will be vulnerable if further marketisation is driven through by the government by, for example, setting up for-profit higher education institutions (see Brooks, 2018a for further discussion):

If commercial providers are allowed a quick, low-quality route into establishing and awarding degrees, those studying and working in the sector are seriously vulnerable to the threat from for-profit organisations looking to move into the market for financial gain rather than any desire to provide students with a high quality education and teaching experience. (English union document $1, \mathrm{p} .5)$

A somewhat similar government discourse is evident in Spain. Students are positioned as vulnerable because, in many cases, they are thought to be poorly served by their higher education institutions. However, the diagnosis and proposed solutions are different in the two countries. In England, as noted above, the problem is seen as stemming from insufficient competition between higher education institutions, and staff focussing on their research rather than teaching. In Spain, it is viewed instead as a result of poor quality staff, and poor pedagogy (treating students as passive and having low expectations of them). In relation to proposed solutions, while England intends to increase marketisation and heighten market signals and metrics related to teaching, Spain sees the solution as lying in the adoption of European standards, employing better staff, and introducing a new regulatory body. In Ireland, it is future students who are seen as vulnerable. The government argues that they are likely to suffer if more money is not put into the system - as a consequence of deteriorating infrastructure, a poor quality student experience, and a high personal financial burden. This provides the rationale, from the government's perspective, for considering new options for higher education funding, including income-contingent loans: 
From these consultations it is clear that there is a need and a desire for urgent reform of the funding landscape. The funding system is simply not fit for purpose. It fails to recognise the current pressures facing higher education institutions or the scale of the coming demographic changes. It also fails to fully recognise the pressures on families and students, not just because of the $€ 3,000$ fee but also the high living and maintenance costs associated with studying and successfully progressing through college. These pressures are now seriously threatening quality within the system and the ability of our sons and daughters to gain the knowledge and develop the capabilities that will enable us to realise our national goals. (Irish government document 3,p.4)

In these four countries, students are treated more sympathetically than in Poland and Denmark (in which they are positioned as objects of criticism, as discussed above). However, as the evidence here demonstrates, the source of their alleged vulnerability differs considerably, not only between nations but also between stakeholder groups. In all cases, it is aligned closely with the particular policy measure they are intent on advancing or opposing.

\section{Investor or investment?}

A further difference in the construction of students can be seen with respect to the concept of 'investment', which is drawn upon in many of the documents. This is most evident in whether they are considered as individual investors or part of a societal investment, and the implications for their rights and responsibilities that are argued to follow from this. The clearest articulation of the former position is seen in England, in a large majority of the government documents and ministerial speeches. The examples below are typical:

The quality of teaching should be among the key drivers of a prospective student's 
investment. (English government document 1)

They [students] have been working hard for their final exams and made a significant investment in higher education. They are looking critically at what they get for that investment. (English speech 2)

This understanding of students is linked closely, in England, to a consumer rights discourse. From this perspective, students are viewed as having rights largely because of the significant financial investment they are making and, because the system to date has not effectively upheld these rights, further marketisation is required (see section on vulnerability above). This emphasis on students as individual investors is largely absent from the policy constructions in most of the other countries. Nevertheless, specific policy actors in both Ireland and Germany indicate that they would welcome a shift towards viewing students in this way:

In contrast to many other countries, however, studying in Germany is not seen by many as an investment in one's own profession and personal career, but rather as a service provided free of charge by the state. It has not yet therefore been possible to involve students in the financing of their studies in any sustainable or comprehensive way. (German employers' document 3)

The more the goals of students, families, employers and the state are transparently being delivered, the more they will each see that their investment is worthwhile and the more compelling the case for investment. (Irish government document 3) 
The dominant discourse in the majority of documents, however, is one which positions students as part of a broader societal investment in education and the public benefits that flow from this. In such cases, students are understood, not as the bearers of consumer rights, but as having certain responsibilities to society.

The Danish higher education system is a very important part of the Danish welfare society.

.... It is perfectly legitimate to expect that students are challenged appropriately and that they invest an appropriate amount of effort and time in their studies. Tax-funded higher education is a unique privilege. ... Higher education requires massive investment by society; everyone pays and, therefore, everyone should benefit. (Danish government document 1)

In this extract, for example, Danish students, as recipients of state support, are expected to prioritise and take seriously their studies. Similar sentiments are expressed by the Spanish government, in noting that, 'In return for this effort of all taxpayers, the grantees [students] were asked to improve their performance, which they have more than fulfilled' (Speech 2). In both cases, it is students' responsibilities, rather than their rights, that are foregrounded.

\section{Spatial provenance}

Finally, a key difference across the policy documents relates to the way in which higher education students are positioned spatially. Students are viewed as Europeans, part of a common European project, in many of the documents from Germany, Spain, Poland and Ireland, while such a perspective is notably absent from the Danish and English policy texts. The most explicit positioning of students as European is seen in Germany, exemplified in the extract below from a speech by the German state secretary for higher education: 
For the 'generation ERASMUS' a Europe with national borders is unthinkable. You feel and understand yourself as a European citizen! .... In the face of nationalism and foreclosure, we are focusing on more mobility of young people, trainees and students in Europe. For nothing defines the European identity more than personal encounters as well as experienced and lived cohesion across national boundaries. (German speech 1)

In a different speech, he argues that education is a key pillar of European identity, and thus educated citizens are key to the future shaping of the EU. European mobility is also discussed very favourably by the Polish government, and argued to offer new and important opportunities to Polish higher education students:

Polish membership of the European Union is a great opportunity for Polish students who are now able to choose the country, higher education institution and field of their study. Students have increasingly better opportunities to learn and obtain the skills required to function in the European labour market. (Polish government document 1)

In Spain, students are also understood as part of the European higher education project by a variety of policy actors. Interestingly, however, European agendas and identities are invoked by different stakeholders to rather different ends. For example, while the Spanish government presents various European initiatives, including further development of European Higher Education Area, as a solution to a series of problems currently faced by the Spanish higher education system - in relation to curriculum content, teaching methods, processes of accreditation and duration of qualification - union documents are critical of some of these initiatives, but deploy European comparisons to argue for the removal of tuition fees for all first degrees in Spain. Here, European frames of reference are used to argue for different policy positions. 
While Denmark and England differ from the other four countries with respect to the absence of any European frames of reference, there is more commonality - across the government documents at least - in relation to internationalisation. This is a strong and pervasive theme across all six countries. Students are held to benefit from international exposure, whether that is through their own outward mobility for part of their degree, the inward mobility of students from other countries, or a more explicitly 'international' curriculum (with, in the case of Poland and Spain, more teaching in English). Countries differ, however, in the extent to which such perspectives are shared by policy actors. In Poland and Spain, the union documents offer an alternative perspective, emphasising, in the case of the former, the importance of students contributing to national economic and social development rather than 'international research excellence', and in the latter, the problems with conforming to an Anglo-Saxon model of higher education (presented as synonymous with 'internationalisation').

\section{Explaining cross-European variation}

While differences such as those outlined above are not exhaustive, they give some indication that higher education students are not understood in the same way across all European nations or indeed by all policy actors within the same nation. We now turn to explaining these differences, considering the impact of funding mechanisms, the domestic political context and geopolitical relations. 


\section{Funding mechanisms}

National differences in the construction of students as both objects of criticism and investors or a social investment can be explained, to some extent, by the different ways in which higher education is funded in the various countries and the impact this has on relationships between the state and students. The high fees paid by students in England (see Table 1), and the state's dependence on this source of income for funding higher education, explains why English students are not criticised in government or business documents - either explicitly or implicitly - in the ways in which we have seen in some other countries. They provide a key means of funding higher education, and alienating this group (through criticism) would presumably be considered a highly risky governmental strategy. Relatedly, the large size of the student population is much more likely to be seen as problematic in countries where fees are fully or largely covered by the state (as in Denmark, for example) than in England, where a large student population is necessary to generate sufficient funds to maintain the higher education sector. Similarly, students' subject choices may be deemed a legitimate concern of the state in nations where higher education remains largely publically-funded, but not in nations such as England where high fees are promoted by the government as a personal investment related closely to the interests and ambitions of individual students. Such differences in funding mechanisms also underpin the differences documented above in relation to whether students are understood as individual investors or a social investment. In England, the policy discourse clearly constructs students as individuals who, through paying high fees, are making an important investment in their future careers and likely earnings. They are bearers of consumer rights, and can expect certain standards and outcomes as a result of their financial commitment. In contrast, in nations where students pay no or low fees, they are understood as part of a societal investment - and thus have particular 
obligations to the tax-payer, such as completing their studies in reasonable time and choosing subjects that the government perceives to be of public benefit.

In some ways, Poland can be seen as an exception to these patterns. Within the policy documents it is largely fee-paying students who come in for most criticism, ${ }^{\mathrm{v}}$ and who are viewed as being closely associated with the decline in both standards and the employmentrelevance of the Polish higher education system. Nevertheless, in other ways, the construction of the student is consonant with broader trends in Poland in relation to the funding of higher education. As Kwiek (2016) has documented, there has been widespread suspicion of both private higher education institutions and the fee-based track within public higher education in Poland and, over recent years, a significant shift towards the 'de-privatisation' of the Polish higher education sector has occurred. Thus, in contrast to in England, fee-paying students are not considered as necessary for the sustainability of higher education institutions but rather as part of the reason why Polish higher education has performed poorly. This provides the context in which they are seen as legitimate objects of criticism - associated with a funding regime deemed in urgent need of reform.

The extant literature has emphasised the impact of funding mechanisms on access to higher education (Callender and Mason, 2017), students' attitudes to their learning (Nixon et al., 2018), and more general messages about the way in which higher education is valued within a society (Collini, 2012). It has also argued that they can have a significant impact on the wider lives of students. Antonucci (2016), for example, has shown how the different ways of funding higher education across Europe can affect: the relationships students have with their parents (if the latter are required to make a substantial financial contribution to their son or daughter's studies); the time available for studying and/or becoming involved in extra- 
curricular activities (which may be compromised if students need to engage in paid employment); and inequalities between students (exacerbated in nations where more emphasis is placed on familial sources of funding). In extending this debate, the data discussed above indicate that differences in funding mechanisms can also inform the way in which students are understood by policymakers and how they are addressed within policy documents. While, on one hand, absolving students from any criticism, as seen in the English documents, can be viewed positively, on the other hand, the underpinning logic that positions them as individual investors, interested primarily in the return they will receive on their financial outlay, tends to obscure both the role of higher education as a public good and the non-economic contributions students necessarily have to make to their own learning. In nations where students have become, at least to some extent, objects of criticism, this can be seen as a mechanism to drive change. As the evidence from Spain - cited above - indicates, students appear to be viewed as malleable actors, who are strongly influenced by the policy context in which they operate. Criticism of them is thus often implicitly criticism of the system in which they find themselves.

\section{Domestic political context}

As noted above, within four of the six countries, students are constructed as, in some ways, vulnerable. Although this relates partially to some of the points made in the preceding section about the relationship between how higher education is funded and seeing students as objects of criticism (i.e. it is hard both to criticise students and present them as vulnerable), it is also consonant with other ways in which young people, in general, are often understood within many European nations and the use that can be made of this within policy texts. They are commonly viewed as lacking in power and/or political agency, and thus in need of protection 
by the state. In England, for example, this view has gained currency through those who have argued that present-day students are 'delicate snowflakes', unable to cope with divergent political views (Finn, 2017) and with a sense of 'diminished subjectivity' (Furedi, 2017). By drawing on this perceived vulnerability as justification for particular policies, governmental positions become harder to critique. This can be seen as an example of what Shore (2011) describes as 'policy as statecraft'. He argues that a key function of policy is legitimation outlining a course of action, and then fixing it within a framework of universal principles. In this case, protection of the vulnerable is the universal principle that is used to justify a wide range of policy measures: increased marketisation in England; the adoption of European standards in Spain; the introduction of more digital technologies in Germany; and consideration of new methods for funding higher education in Ireland. Moreover, the idea of vulnerability also articulates with the conception of students as the future, a key means of securing the economic and social prosperity of the nation state, rather than an important political component of the present. Indeed, Lesko (2011) has argued that young people have been defined 'always "becoming", waiting for the future to arrive' (p.131), a definition which has provoked, she maintains, 'endless watching, monitoring and evaluating' (p. 111) on the part of adults, and a passivity on the part of young men and women as they are told that only the future matters, and that it is the end of the adolescent story that is key. Such rhetorical manoeuvres within policy help to neutralise any disagreement with the particular changes proposed; it is hard to oppose measures intended to protect the relatively powerless or ensure the future of one's own nation-state.

The positioning of students as objects of criticism, while clearly different in emphasis, can happen for similar reasons i.e. it can constitute an important means of securing public support for particular domestic policy measures. Indeed, in Denmark, the criticism of 
students discussed previously may, in part, be a response to public condemnation of 'lazy students' in the national press (Ulriksen, 2016) and also a means through which the government can reassure the tax-payer that action is being taken to ensure that public money is being used effectively and appropriately (by requiring students to complete their education more quickly). (Here there are also clear links back to the way in which higher education is funded, discussed above.) Similarly, in Poland, the figure of the 'low quality' student, studying a subject not well-aligned to the labour market, can be seen as a foil for the introduction of a variety of (controversial) measures intended to increase the quality of higher education (Kwiek, 2016). Here, constructions of the student are highly performative, making the contestation of policy by non-governmental actors more difficult.

Similar arguments can be made in relation to constructing students as either investors, with associated rights, or as a societal investment, with consequent responsibilities. In countries where higher education is funded largely through public sources, an emphasis on the responsibilities of students may help to assuage the concerns of tax-payers about the cost of higher education, whereas in England, with students and/or their families expending large amounts and/or accruing large debts for study, an emphasis on their rights as investors may reassure these parties that their interests are being looked after by the government. Clearly, the language used in policy documents is also influenced by the wider political climate and policy regime within individual nations; policymakers have to be cognisant of what is an acceptable policy (and acceptable language with which to talk about it), as well as what is, to them, a desirable one (Klemenčič, 2014). As market discourse is now firmly established within education policy in England - and much less contested than in other European nations (ibid.) - it is thus unsurprising that English policy constructs students in economistic terms considerably more frequently in the other five nations in the research. 


\section{Geopolitical relations}

A country's geopolitical position also informs the way in which it constructs its higher education students. The strong framing of students as Europeans in Germany, Ireland, Poland, Spain but not in Denmark and England is largely consonant with the respective relationships these countries have with Europe, in general, and the EU in particular. Germany clearly has a long history as a founder member of key European associations (West Germany was one of the first members of the European Coal and Steel Community, from which the European Economic Community and later the EU evolved) and currently occupies a central position in the 'European project' (Kundnani, 2014). It is thus unsurprising that higher education students in Germany are also imbued with a strong European identity within policy constructions. Within Spain, however, an equally positive orientation to Europe within policy has been explained in a rather different way. Bonal and Tarabini (2013), analysing the schools sector, have argued that, because of Spain's 'semi-peripheral' position within the EU, 'the education reforms and proposals of the Spanish national and regional governments are commonly presented as policies to improve the position of the country within the European context, in both educational and socio-economic terms' (p.337). Moreover, they contend that Spanish official discourse constantly underlines the advantages of Europeanisation as a means of advancing both social and economic progress: "in order to become "real Europeans" it is crucial to follow the reforms already implemented by other European countries' (p.337).

In contrast, England has had a notably different relationship with the EU. Its Euroscepticism has been widely documented across politics in general (Gifford, 2014), culminating in the vote in June 2016 to leave the EU. This has affected not only how policies 
are framed and students understood but also the substantive content of policies themselves. For example, Alexiadou and Lange (2014) have catalogued the various administrative strategies the UK government has used to minimise EU influence on the national education space. These have included: affirming the importance of national sovereignty at higher levels of government; counting things in slightly different ways, to minimise discrepancies between EU and UK policy objectives; subsuming EU targets within broader UK ones; and, in the cases where it has to accept an EU proposal it is not in favour of, not making much effort to translate it into national policy (ibid.). Alexiadou and Lange cite the Bologna mobility target (that 20 per cent of higher education students should have had a cross-border mobility experience by 2020) as an example of the last point - civil servants passed this on to UK higher education institutions as merely a 'suggestion'.

Denmark can be seen as occupying a third, and contrasting position. Danish higher education policy has been more significantly influenced by that in England by various EU policies. Degu (2015) has argued that many of the major reforms that have been carried out in Denmark since the start of the $21^{\text {st }}$ century have been underpinned by the principles of the Bologna project - namely flexibility, entrepreneurialism, accountability and new managerialism - principles that were at odd with the social democratic principles that had informed Danish higher education previously. These European principles underpinned the governance reforms introduced in Denmark in 2003 (in which universities gained more autonomy, but were held accountable for specific government-defined targets), and a series of institutional mergers in 2006-07 (Degn and Sorensen, 2015; Mosneaga and Agergaard, 2012). Nevertheless, the absence of any European framing of Danish students, within the analysed documents, can be seen as consonant with the Euroscepticism that has infused broader politics. This has been evident, not in the 'hard' form played out in the England, in which 
withdrawal from the EU is advocated - but in a 'softer' version in which specific EU policies have been publically critiqued (Fitzgibbon, 2013). Indeed, Denmark has witnessed both leftwing and right-wing party Euroscepticism, with a relatively high level of public opposition to both political integration and monetary union (Nielsen, 2015). As a consequence of this broader political culture, it is perhaps unsurprising that the Danish documents - like their English equivalents - refrain from positioning higher education students as Europeans.

As noted above, a rather different picture emerges with respect to internationalisation. Across all six countries, governments tend to portray higher education students as internationally-focussed - through being mobile themselves, having good inter-cultural skills and/or competing successfully in global graduate labour markets. This reflects welldocumented trends across higher education more generally in which universities are increasingly being drawn into a rapidly globalising marketplace (Mosneaga and Agergaard, 2012) - influenced by new scalar politics in which the nation state remains important, but works in a different way, with the aim of securing an advantageous position for national economies within global markets (Lingard and Rowelle, 2011). Such shifts have been manifest in the increasingly important role of global university rankings (Jöns and Hoyler, 2013) and the emphasis placed on developing 'world class universities' (Marginson, 2018) in many parts of the world. Nevertheless, our analysis has also shown how such agendas are contested in some, but not all, of the six countries. Unions in both Poland and Spain offer alternative narratives, which problematise an international emphasis, and suggest that focussing on global performance (through, for example, concentrating resources on a small number of elite institutions and offering more courses in English) is to the detriment of national development and the preservation of national identity. Such narratives demonstrate that understandings of students may vary significantly within (as well as across) nations, 
building on previous work that has highlighted the way in which higher education policy more generally is often resisted and/or taken up in different ways by non-governmental actors (e.g. Santiago and Carvallo, 2012; Kwiek, 2015).

\section{Conclusion}

By drawing on a wide range of policy texts from six nations, this article has shown that the ways in which higher education students are constructed within policy differ quite substantially across Europe. This has implications for both students themselves and for broader debates about European homogenisation. As Lomer (2017) has noted, because policy documents are typically written by those occupying powerful positions in society, the language they use and the constructions they advance are likely to become part of entrenched, dominant discourses. Although students, like other social actors, have the capacity to rework 'top down' policy imperatives to some extent (Shore and Wright, 2011), dominant policy constructions nevertheless have the capacity to influence how students are thought about and the way in which they think about themselves. Thus, seeing oneself as an object of criticism (for example, in Denmark) or as an individual investor imbued with consumer rights (as in England) may affect how one feels about being a student, and one's relationship with those who hold power. Students who come to see themselves as individual investors may, for example, be less likely to participate in collaborative forms of learning and value the noneconomic rewards of studying. Such impacts may also be differentiated by social background. Students from families without a history of higher education, who are unsure about whether they will 'fit in', may be put off applying entirely if they believe that students are not always viewed positively by the government. 
The differences between countries, highlighted in the paper, indicate that these dominant discourses vary considerably across the continent (and are also, in some cases, contested within individual nations). This diversity raises important questions about assumptions that are sometimes made, within the academic literature and among social commentators more generally, about the homogenisation of higher education across Europe. Moutsios (2013), for example, has argued that the Bologna Process, actively led by the EU, has introduced corporate management to universities across Europe, 'disintegrating the academic community, subduing the staff as a workforce under surveillance and positioning students as consumers' (p.40) (italics added) - and that such measures have been broadly accepted by national governments and representatives of university staff and students. In contrast, the data presented in this article have emphasised instead the complexity inherent in such policies of policy transfer and the influence exerted by national political priorities and geopolitical relationships. In this way, it supports those who have argued, with respect to higher education policy in general, that different socio-political contexts can have a significant influence on the way in which European standardisation processes are rolled out (Wodak and Fairclough, 2010), and that European policy imperatives often provide no more than a 'script' that national actors interpret according to their own national and institutional traditions (Capano and Paittoni, 2011). In advancing such debates, the article has shown how the specifics of higher education funding can also be influential - at least in the way in which students are understood - not just more general socio-political orientations. Finally, in highlighting some of the key ways in which constructions in England differ from those evident in the other five nations in the study, the article has also shown that differences endure between Anglo-American models, on one hand, and those in continental Europe, on the other hand - with the latter still remaining some distance from fully-fledged consumerism 
(McEldowney et al., 2009). Assertions about European homogenisation thus appear to be premature.

\section{Acknowledgements}

I would like to thank the European Research Council for the award of a Consolidator Grant (reference 681018_EUROSTUDENTS), which funded this research.

\section{References}

Alexiadou, N. and Lange, S. (2014) Policy space and the governance of education: transnational influences on institutions and identities in the Netherlands and the UK, Comparative Education, 49, 3, 344-360.

Antonucci, L. (2016) Student Lives in Crisis. Deepening inequality in times of austerity Bristol, Polity Press.

Ashwin, P., Abbas, A. and McLean, M. (2015) Representations of a high quality system of undergraduate education in English higher education policy documents, Studies in Higher Education, 40, 4, 610-623.

Bacchi, C. (2000) Policy as discourse: What does it mean? Where does it get us? Discourse: Studies in the Cultural Politics of Education, 21, 1, 45-57. 
Ball, S. (1990) Politics and Policy Making in Education: explorations in policy sociology New York, Routledge.

Batory, A. and Lindstrom, N. (2011) The power of the purse: supranational entrepreneurship, financial incentives, and European higher education policy, Governance, 24, 2, 311-329.

Bonal, X. and Tarabini, A. (2013) The role of PISA in shaping hegemonic educational discourses, policies and practices: the case of Spain, Research in Comparative and International Education, 8, 3, 335-341.

Brooks, R. (2018a) The construction of higher education students in English policy documents, British Journal of Sociology of Education, 39, 6, 745-761.

Brooks, R. (2018b) Understanding the higher education student in Europe: a comparative analysis, Compare: A Journal of Comparative and International Education, 48, 4, 500-517.

Callender, C. and Mason, G. (2017) Does Student Loan Debt Deter Higher Education Participation? New Evidence from England, Annals of the American Academy of Political and Social Science, 671, 1, 20-47.

Capano, G. and Piattoni, S. (2011) From Bologna to Lisbon: the political uses of the Lisbon 'script' in European higher education policy, Journal of European Public Policy, 18, 4, 584606. 
Collini, S. (2012) What are Universities For? London, Penguin.

Degn, L. and Sørensen, M. (2015) From collegial governance to conduct of conduct: Danish universities set free from the service of the state, Higher Education, 69, 931-946.

Epsing-Anderson, G. (1990) The Three Worlds of Welfare Capitalism Cambridge, Polity Press.

Eurydice (2017) National Student Fee and Support Systems in European Higher Education 2017/18 Available online at:

https://webgate.ec.europa.eu/fpfis/mwikis/eurydice/images/e/e7/214_EN_Fees_and_support 2017_18.pdf (Accessed 23/4/18).

Finn, K. (2017) Snowflakes and Smashed Avocados: Exploring the Contradictory Representations of the Higher Education Generation in times of Political Crisis and Change. Presentation to the SRHE annual conference, Newport, Wales, December 2017.

Fitzgibbon, J. (2013) Citizens against Europe? Civil society and Eurosceptic protest in Ireland, the United Kingdom and Denmark, Journal of Common Market Studies, 51, 1, 105121.

Foucault, M. (1986) The Archaeology of Knowledge London, Tavistock Publications.

Furedi, F. (2017) What's Happened to the University? A Sociological Exploration of its Infantilisation London, Routledge 
Gifford, C. (2014) The Making of Eurosceptic Britain (second edition) London, Routledge.

Jöns, H. and Hoyler, M. (2013) Global geographies of higher education: The perspective of world university rankings, Geoforum, 46, 45-59.

Klemenčič, M. (2014) Student power in a global perspective and contemporary trends in student organising, Studies in Higher Education, 39, 3, 396-411.

Kundnani, H. (2014) The Paradox of German Power London, C. Hurst and Co.

Kwiek, M. (2015) The unfading power of collegiality? University governance in Poland in a European comparative and quantitative perspective, International Journal of Educational Development, 43, 77-89.

Kwiek, M. (2016) From production (of the expansion era) to de-privatisation (of the contraction era), in: Slaughter, S. and Taylor, B. (eds) Higher Education, Stratification, and Workforce Development, Higher Education Dynamics 45.

Leathwood, C. (2006) Gender, equity and the discourse of the independent learner in higher education, Higher Education, 52, 611-633.

Lesko, N. (2001) Act Your Age! A Cultural Construction of Adolescence New York, RoutledgeFalmer. 
Lingard, B. and Rawolle, S. (2011) New scalar politics: implications for education policy, Comparative Education, 47, 4, 489-502.

Lomer, S. (2017) Recruiting International Students in Higher Education. Representations and Rationales in British Policy London, Palgrave.

Maguire, M., Hoskins, K., Ball, S. and Braun, A. (2011) Policy discourses in school texts, Discourse: Studies in the Cultural Politics of Education, 32, 4, 597-609.

Marginson, S. (2018) The new geopolitics of higher education London, UCL centre for Research into Global Higher Education.

McEldowney, M., Gaffkin, F. and Perry, D. (2009) Discourses of the contemporary urban campus in Europe: intimations of Americanisation? Globalisation, Societies and Education, $7,2,131-149$.

Mosneaga, A. and Agergaard, J. (2012) Agents of internationalisation? Danish universities' practices for attracting international students, Globalisation, Societies and Education, 10, 4, $519-538$.

Moutsios, S. (2013) The de-Europeanization of the university under the Bologna process. Thesis Eleven, 119, 1, 22-46.

Nielsen, J. H. (2015) The pragmatic Euroscepticism of Scandinavia, in: Leruth, B., Startin, N. and Usherwood, S. (eds) Routledge Handbook of Euroscepticism London, Routledge. 
Nielsen, G. and Sarauw, L. L. (2017) Tuning Up and Tuning In: How the European Bologna Process Is Influencing Students' Time of Study, in: Wright, S. and Shore, C. (eds) The Death of the Public University? New York, Berghahn Press.

Nixon, E., Scullion, R. and Hearn, R. (2018) Her majesty the student: marketised higher education and the narcisstic (dis)satisfactions of the student-consumer, Studies in Higher Education, 43, 6, 927-943.

O'Connor, S. (2018) Problematising strategic internationalisation: tensions and conflicts between international student recruitment and integration policy in Ireland, Globalisation, Societies and Education, 16, 3, 339-352.

Oliver, M. (2016) Self-control? Students' quantified self in the digital university. Presentation to the SRHE annual conference, Newport, Wales, December 2016.

Philips, D. and Schweisfurth, M. (2014) Comparative and International Education London, Continuum.

Sabri, D. (2010) Absence of the academic from higher education policy, Journal of Education Policy, 25, 2, 191-205.

Santiago, R. and Carvallo, T. (2012) Managerialism rhetorics in Portuguese higher education, Minerva, 50, 511-532. 
Shore (2011) Espionage, Policy and the Art of Government, in: Shore, C., Wright, S. and Però, D. (eds) Policy Worlds. Anthropology and the Analysis of Contemporary Power New York, Berghahn Books.

Shore, C. and Wright, S. (2011) Conceptualising Policy: Technologies of Governance and the Politics of Visibility, in: Shore, C., Wright, S. and Però, D. (eds) Policy Worlds. Anthropology and the Analysis of Contemporary Power New York, Berghahn Books.

Sin, C. and Neave, G. (2016) Employability deconstructed: perceptions of Bologna stakeholders, Studies in Higher Education, 41, 8, 1447-1462.

Tavares, O. and Cardoso, S. (2013) Enrolment choices in Portuguese higher education: do students behave as rational consumers? Higher Education, 66, 297-309.

Ulriksen, L. (2016) Students' time budget practices: This was the time of our lives. Presentation to the SRHE annual conference, Newport, Wales, December 2016.

Voegtle, E., Knill, C. and Dobbins, M. (2011) To what extent does transnational communication drive cross-national policy convergence? The impact of the Bologna Process on domestic higher education policies, Higher Education, 61, 77-94.

Wodak, R. and Fairclough, N. (2010) Recontextualising European higher education policies: the cases of Austria and Romania, Critical Discourse Studies, 7, 1, 19-40. 
Wright, S. and Shore, C. (eds) (2017) The Death of the Public University? New York, Berghahn Press.

Zippel, K., Ferree, M. and Zimmermann, K. (2016) Gender equality in German universities: vernacularizing the battle for the best brains, Gender and Education, 28, 7, 867-885. 
Table 1. Characteristics of the countries involved in the research

\begin{tabular}{|c|c|c|c|c|}
\hline Country & Welfare regime & $\begin{array}{l}\text { Access- } \\
\text { ion to } \\
\text { the EU }\end{array}$ & $\begin{array}{l}\text { Tuition fees for full-time } \\
\text { undergraduates (2017/18) }\end{array}$ & $\begin{array}{l}\text { Student support for full-time } \\
\text { undergraduates (2017/18) - with amounts } \\
\text { per annum }^{v i}\end{array}$ \\
\hline Denmark & $\begin{array}{l}\text { Social } \\
\text { democratic }\end{array}$ & 1973 & No tuition fees & $\begin{array}{l}\text { c. } 85 \text { per cent receive needs-based grants } \\
\text { (of up to } € 9703 \text { ); loans available to those } \\
\text { entitled to state grant }\end{array}$ \\
\hline England & Liberal & $\begin{array}{l}1973 \text { (to } \\
\text { leave in } \\
\text { 2019) }\end{array}$ & $\begin{array}{l}\text { High fees, typically } £ 9250 \\
\text { per year }\end{array}$ & No grants; loans available to all \\
\hline Germany & Corporatist & 1952 & $\begin{array}{l}\text { No tuition fees; } \\
\text { administrative fee of up to } \\
€ 300 \text { per semester }\end{array}$ & $\begin{array}{l}\text { c. } 25 \text { per cent of students receive need- } \\
\text { based grants (up to } € 8820 \text { - includes } \\
\text { integrated loan) }\end{array}$ \\
\hline Ireland & $\begin{array}{l}\text { Catholic } \\
\text { corporatist }\end{array}$ & 1973 & $\begin{array}{l}\text { No tuition fees; ‘student } \\
\text { contribution' of } € 3000 \text { per } \\
\text { year }\end{array}$ & $\begin{array}{l}\text { c. } 44 \text { per cent of students receive need- } \\
\text { based grants (up to } € 5915 \text { ); no loans } \\
\text { available }\end{array}$ \\
\hline Poland & $\begin{array}{l}\text { Post- } \\
\text { Communist }\end{array}$ & 2004 & $\begin{array}{l}\text { No tuition fees; one-off } \\
\text { administrative fee of c.€47 } \\
\text { per year }\end{array}$ & $\begin{array}{l}\text { c. } 16 \text { per cent of students receive need- } \\
\text { based grants }(€ 1244) \text { and } 8 \text { per cent merit- } \\
\text { based grants (average } € 1113) \text {; loans } \\
\text { available to those on lower incomes }\end{array}$ \\
\hline Spain & $\begin{array}{l}\text { Mediterranean/ } \\
\text { sub-protective }\end{array}$ & 1986 & $\begin{array}{l}\text { c. } 71 \text { per cent of students } \\
\text { pay fees; average amount } \\
\text { of } € 1213 \text { per year }\end{array}$ & $\begin{array}{l}\text { c. } 30 \text { per cent of students receive need- } \\
\text { based grants (up to } € 6682 \text { ); no loans } \\
\text { available }\end{array}$ \\
\hline
\end{tabular}

Table 2. Analysed documents referenced in the article with identifiers

\begin{tabular}{|c|c|}
\hline Label & Full reference \\
\hline Danish government document 1 & $\begin{array}{l}\text { Expert Committee on Quality (2015) New Ways \& High Standards - the } \\
\text { committee on quality's final reform proposals for Danish higher } \\
\text { education. }\end{array}$ \\
\hline Danish government document 2 & $\begin{array}{l}\text { Ministry of Finance (2016) A Stronger Denmark - a more robust SU } \\
\text { system (original document in Danish) }\end{array}$ \\
\hline Danish speech 1 & Tornaes, U. (2016) Education is key to freedom \\
\hline English government document 1 & $\begin{array}{l}\text { Department for Business, Innovation and Skills (2016) Success as a } \\
\text { Knowledge Economy: Teaching Excellence, Social Mobility and Student } \\
\text { Choice (Cm 9258) London, DBIS. }\end{array}$ \\
\hline English government document 2 & $\begin{array}{l}\text { Department for Business, Innovation and Skills (2016) Success as a } \\
\text { Knowledge Economy: Teaching Excellence, Social Mobility and Student } \\
\text { Choice (Cm 9258) London, DBIS. [White Paper] }\end{array}$ \\
\hline English speech 2 & $\begin{array}{l}\text { Johnson, J. (2015) Teaching at the Heart of the System, Universities UK } \\
\text { annual conference } 1 \text { July } 2015\end{array}$ \\
\hline English union document 1 & $\begin{array}{l}\text { University and College Union (2016) Higher Education and Research } \\
\text { Bill: Public Bill Committee. Written evidence from the University and } \\
\text { College Union (UCU) }\end{array}$ \\
\hline German employers' docu & $\begin{array}{l}\text { BDA (Confederation of German Employers' Associations) (2013) } \\
\text { University Funding. Holistic, transparent and performance-oriented } \\
\text { April } 2013 \text { (original document in German) }\end{array}$ \\
\hline German speech 1 & $\begin{array}{l}\text { Rachel, T. (2017) For good education in Europe: a successful Erasmus } \\
\text { programme (original document in German) }\end{array}$ \\
\hline German union document 5 & $\begin{array}{l}\text { GEW (Trade Union for Education and Science) (2017) Education in a } \\
\text { Digital World. } 10 \text { May } 2017 \text { (original document in German) }\end{array}$ \\
\hline Irish government document 3 & $\begin{array}{l}\text { Expert Group on Funding for Higher Education (July 2016) Investing in } \\
\text { National Ambitions: A Strategy for Funding Higher Education Dublin, } \\
\text { Department of Education and Skills. }\end{array}$ \\
\hline Polish $g$ & $\begin{array}{l}\text { Ministry of Science and Higher Education (2013) Amendment to Law of } \\
\text { Higher Education - Justification }\end{array}$ \\
\hline
\end{tabular}




\begin{tabular}{ll}
\hline Polish government document 4 & $\begin{array}{l}\text { Ministry of Science and Higher Education (2016) The Law on Higher } \\
\text { Education: Ten Key Issues (original document in Polish) }\end{array}$ \\
\hline Spanish government document 3 & $\begin{array}{l}\text { ANECA (National Agency for Quality Assessment and Accreditation of } \\
\text { Spain) (no date given, but assume 2012/3) Strategic Plan 2013-16 (but } \\
\text { later extended to cover 2017 as well) }\end{array}$ \\
\hline
\end{tabular}

\footnotetext{
i The article uses the term 'European policy' to refer to initiatives taken by the European Union (for example, the Erasmus scheme) as well as those pursued by European countries without necessarily being part of EU programmes (for example, the Bologna Process and establishment of a European Higher Education Area). ii In Poland, no relevant employer documents were identified. Thus, the Polish sample comprises only 12 documents.

iii Because of the selection criteria used, the date of document publication varies from country to country. Most, however, were published between 2015 and 2017.

iv The full reference for this (and the other documents referenced in this article) is provided in Table 2. Due to limitations of space, it is not possible to provide details of all 92 documents analysed. The numbering of documents relates to that used across the larger project.

${ }^{v}$ In Poland, fees are charged to part-time students, but not those studying on a full-time basis (see Table 1).

${ }^{\text {vi }}$ Source: Eurydice (2017)
} 